Journal of Advanced Research in Fluid Mechanics and Thermal Sciences

Journal homepage: www.akademiabaru.com/arfmts.html ISSN: 2289-7879

\title{
A Study on the Influence of Oil Palm Trunk Fiber on Ultrasonic Pulse Velocity (UPV) and Shrinkage of Foamcrete
}

\author{
Md Azree Othuman Mydin ${ }^{1,}{ }^{*}$, Mohd Nasrun Mohd Nawi ${ }^{2}$, Muhammad Arkam Che Munaaim ${ }^{3}$, \\ Othman Mohamed ${ }^{4}$
}

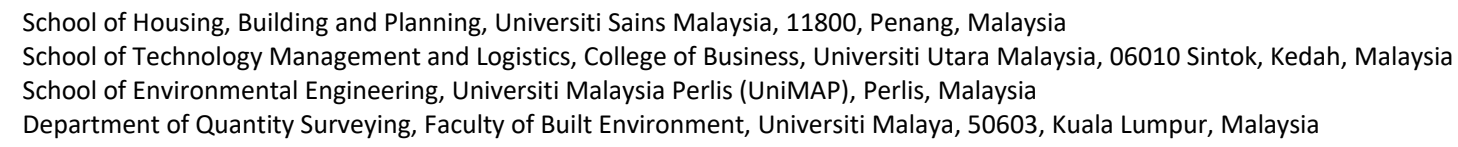

\section{Article history:}

Received 9 May 2020

Received in revised form 3 September 2020

Accepted 10 September 2020

Available online 18 October 2020

Keywords:

Ultrasonic pulse velocity; shrinkage; pundit; oil palm fiber; biomass waste
Presently there is increasing attention in utilization foamcrete as a lightweight nonstructural and semi-structural element in buildings to take advantage of its excellent insulation properties. Though, foamcrete has been noticed to have some disadvantages: considerable brittleness; results in low compressive and flexural strength, poor fracture toughness, poor resistance to crack propagation and low impact strength. Hence this study is intended to look into the potential of oil palm trunk (OPT) fiber in enhancing the engineering properties of foamcrete. There are 2 engineering properties will be focused in this study which are ultrasonic pulse velocity and drying shrinkage. Two densities of foamcrete of $600 \mathrm{~kg} / \mathrm{m3}, 1200 \mathrm{~kg} / \mathrm{m} 3$ were cast and tested. The ratio of cement, sand and water used in this study was 1:1.5:0.45. OPT fibers were used as additives at $0.15 \%, 0.30 \%, 0.45 \%$ and $0.60 \%$ by volume of the total mix. Test results indicated that the engineering properties of foamcrete reinforced with OPT fiber had amplified thoroughly.

\section{Introduction}

For the past few years, the call for green concrete technology is encouraged by augmented rules and strategies in turn to diminish the greenhouse gas emission and lessening the carbon footprint $[1,2]$. Additionally, the construction industry in Malaysia is embracing green construction owing to project requirements for Green Building Index (GBI) certification [3]. As far as GBI rating tool is concerned, it was first introduced in Malaysia back in year 2005 in which the main objective was to enhance awareness among industrial players and to encourage sustainable construction in the built environment [4]. Additionally, universal apprehension and governance on carbon footprint emissions

\footnotetext{
* Corresponding author.

E-mail address: azree@usm.my

https://doi.org/10.37934/arfmts.76.2.111117
} 
has driven research into green concrete throughout the world which special attention been given on environmental deliberations with respect to base mix material sourcing, concrete mix design, design of structural component, construction method, construction technology and last but not least the aspect of concrete structure maintenance [5].

Therefore, the concrete industry players in Malaysia can play a huge role towards achieving sustainable development of the society holistically [6]. Oil Palm Trunk (OPT) refers to agricultural waste or by-products that can be obtained through the distribution of palm oil and can be accumulated in a large amount in Malaysia. Moreover, it should be understood that OPT fibers are often discarded as agricultural wastes [7]. Nonetheless, abundant arrangements intent on the lower cost of materials have been recommended despite the important need of green concrete production and reasonably priced housing system for both whom live at the countryside and metropolitan areas in Malaysia. Therefore, this research aims to investigate the potential of oil palm trunk (OPT) fiber on drying shrinkage and ultrasonic pulse velocity of foamcrete

\section{Materials}

The mix constituents included Ordinary Portland cement (OPC), fine aggregate, clean water and surfactant. The foamcrete mixture's proportion of cement, sand and water is 1:1.5:0.45. The target densities were $600 \mathrm{~kg} / \mathrm{m}^{3}$ and $1200 \mathrm{~kg} / \mathrm{m}^{3}$. The water-cement ratio was set up at 0.45 . While the oil palm trunk fiber was supplied by DR-N Technologies. The oil palm trunk fiber was cleaned in tap water and was leave it dried for 48 hours before mixing. There were 4 different volume fractions were used which were $0.15 \%, 0.30 \%, 0.45 \%$ and $0.60 \%$. The oil palm trunk fiber fibers were cut into $19 \mathrm{~mm}$ length. Ultrasonic pulse velocity test and drying shrinkage test were conducted which will be explained in the following section.

\section{Experimental Setup}

\subsection{Ultrasonic Pulse Velocity Test}

Ultrasonic pulse velocity is the non-destructive test to know the concrete characterization. The ultrasonic wave is generated by a transducer in contact with the test material either in the form of compressional wave or shear wave. These waves are detected by the second transducer placed on the other face of the test material. The ultrasonic wave velocity depends on the elastic properties and density of the concrete ( $\mathrm{ACl} 544.1 \mathrm{R}, 1996)$. The travel time and energy decay through the material have been processed and displayed by the digital computer connected with the transducers. Using the travel time and measured dimension, the ultrasonic pulse velocity has been calculated. Figure 1 shows the setup for ultrasonic pulse velocity test. 


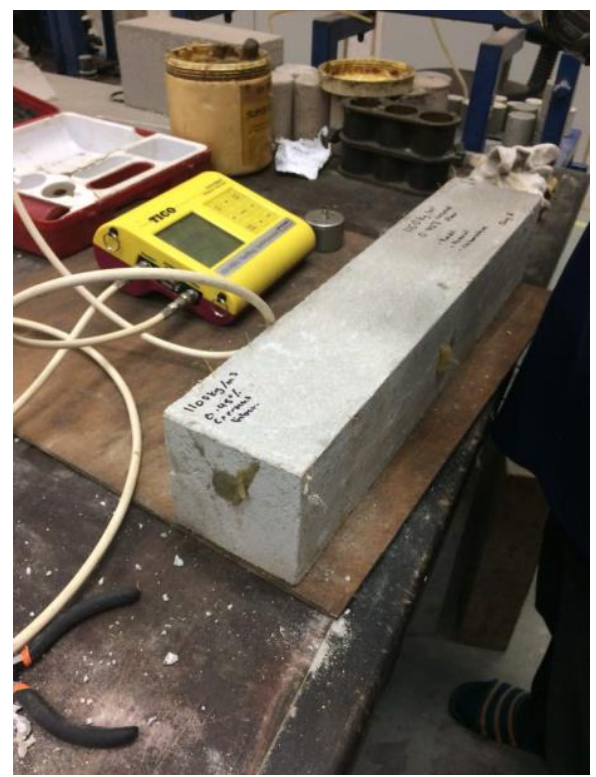

Fig. 1. Ultrasonic pulse velocity test

\subsection{Drying Shrinkage Test}

The aim of this experimental test is to justify the capability of fibres in resisting volume changing. The test procedure is in compliance with ASTM C878. The sample test must be a prism: $75 \mathrm{~mm}$. square with a gage length of $250 \mathrm{~mm}$ and an overall estimated length (including the length of the rod and cap nuts) of $290 \mathrm{~mm}$. A minimum number of three samples were set up for each test in order to get the average result. Figure 2 shows the apparatus that measures the drying shrinkage of foamcrete. The initial length measurements were taken using a length comparator that is capable of adjusting the measurements to $0.001 \mathrm{~mm}$ with $250 \mathrm{~mm}$ invar bar. The length of the comparator was calibrated against the reference invar bar in each of the sample.

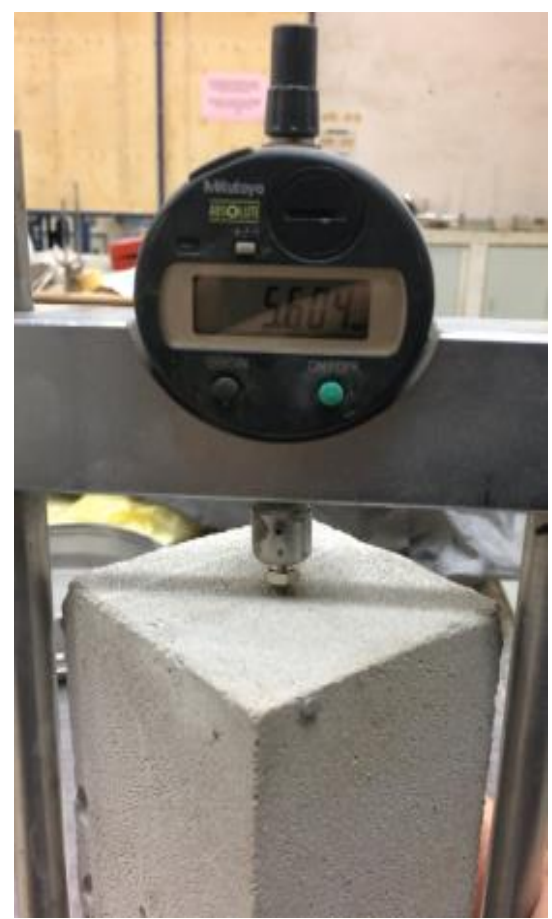

Fig. 2. Porosity test through vacuum saturation method 


\section{Results and Discussion}

\subsection{Ultrasonic Pulse Velocity}

Ultrasonic pulse velocity (UPV) is one of the most prevalent non-destructive methods implemented to evaluate concrete toughness. Though it is not a precise apparatus to measure the pore structures in concrete, but it can still provide an excellent initial forecast of the quality of concrete based material. Figure 3 shows the ultrasonic pulse velocity (UPV) results for both densities tested in this study. It can be seen from Figure 3 that higher addition of coir fiber in the base mix has enhanced the ultrasonic pulse velocity (UPV) in comparison with control specimen. For both densities, $0.45 \%$ coconut fiber inclusion gave an excellent ultrasonic pulse velocity (UPV) reading of $1310 \mathrm{~m} / \mathrm{s}$ for $600 \mathrm{~kg} / \mathrm{m}^{3}$ density and $3318 \mathrm{~m} / \mathrm{s}$ for $1200 \mathrm{~kg} / \mathrm{m}^{3}$. This might be associated to the hydration mechanism of the binary cementitious system in lightweight foamcrete for fiber with higher percentages of oil palm trunk fiber in the base mix [8-10].

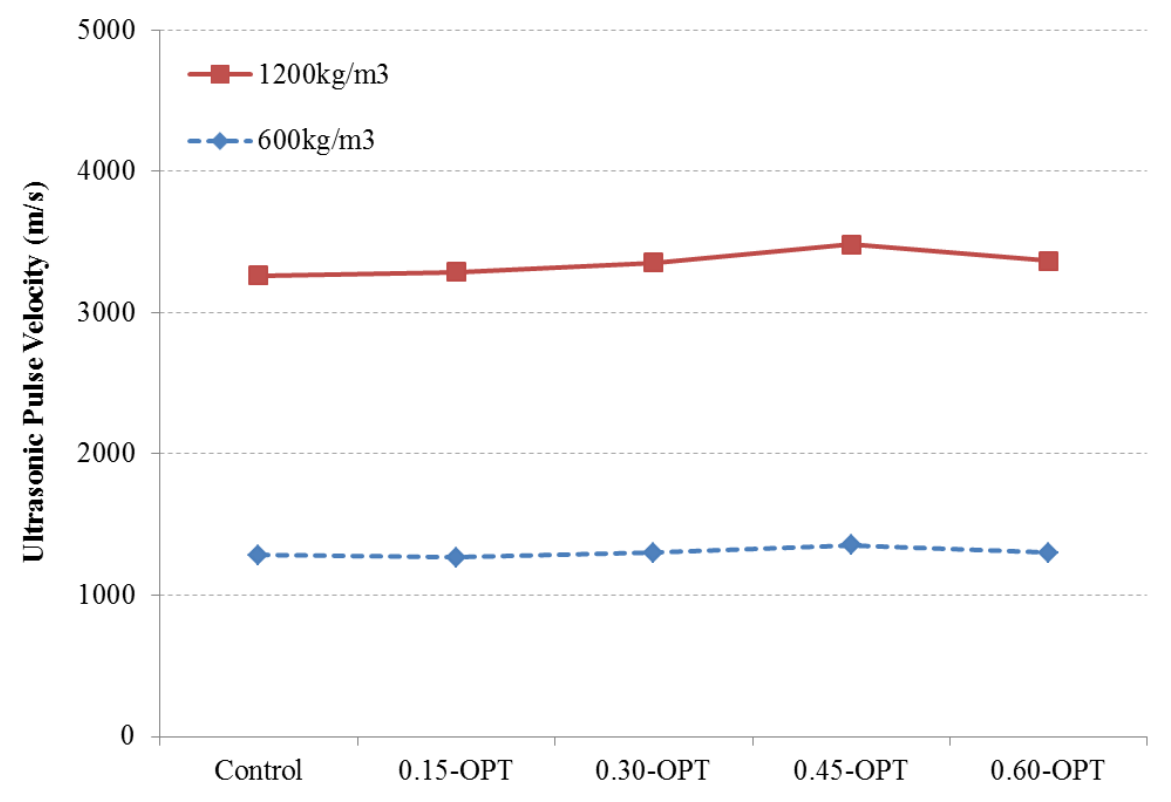

Fig. 3. Ultrasonic pulse velocity of foamcrete with different percentages of oil palm trunk fiber

\subsection{Drying Shrinkage}

The result for drying shrinkage is presented in Figure 4-5. In this case, it can be clearly observed that drying shrinkage for all specimens is dramatically high in early age until 30 days and then it continues to increase slowly. The control mixes are shown to have higher drying shrinkage for 600 $\mathrm{kg} / \mathrm{m}^{3}$ and $1200 \mathrm{~kg} / \mathrm{m}^{3}$ densities. Moreover, the addition of OPT causes the drying shrinkage of lightweight foamcrete specimens to improve drastically. Meanwhile, the findings show that for OPT of $0.45 \%$ gave the best results for both densities. Therefore, it can be concluded that the inclusion of OPT in lightweight foamcrete contributes to better shrinkage prevention. The addition of OPT in foamcrete provides the best outcomes in lessening the shrinkage in contrast to control mix of foamcrete.

The OPT fiber reacts as aggregates or filler that give compact composition of microstructure which in this way lessens as well as decreases the size and measures of pores [11]. Generally, the major factor that influences the shrinkage behavior of a concrete is cement paste. The shrinkage of foam concrete is a component of foam volume which is consequently by implication identified with 
the amount and properties of shrinkable paste. Moreover, shrinkage tends to be higher in the scope of low dampness content. As expressed by Nambiar and Ramamurthy [12], the reduction of drying shrinkage is caused by increase in the foam content. Lesser drying shrinkage at higher foam volume is caused by lower substance of paste in the mix, thus consequently cause lower content of pores to affect the shrinkage [13].

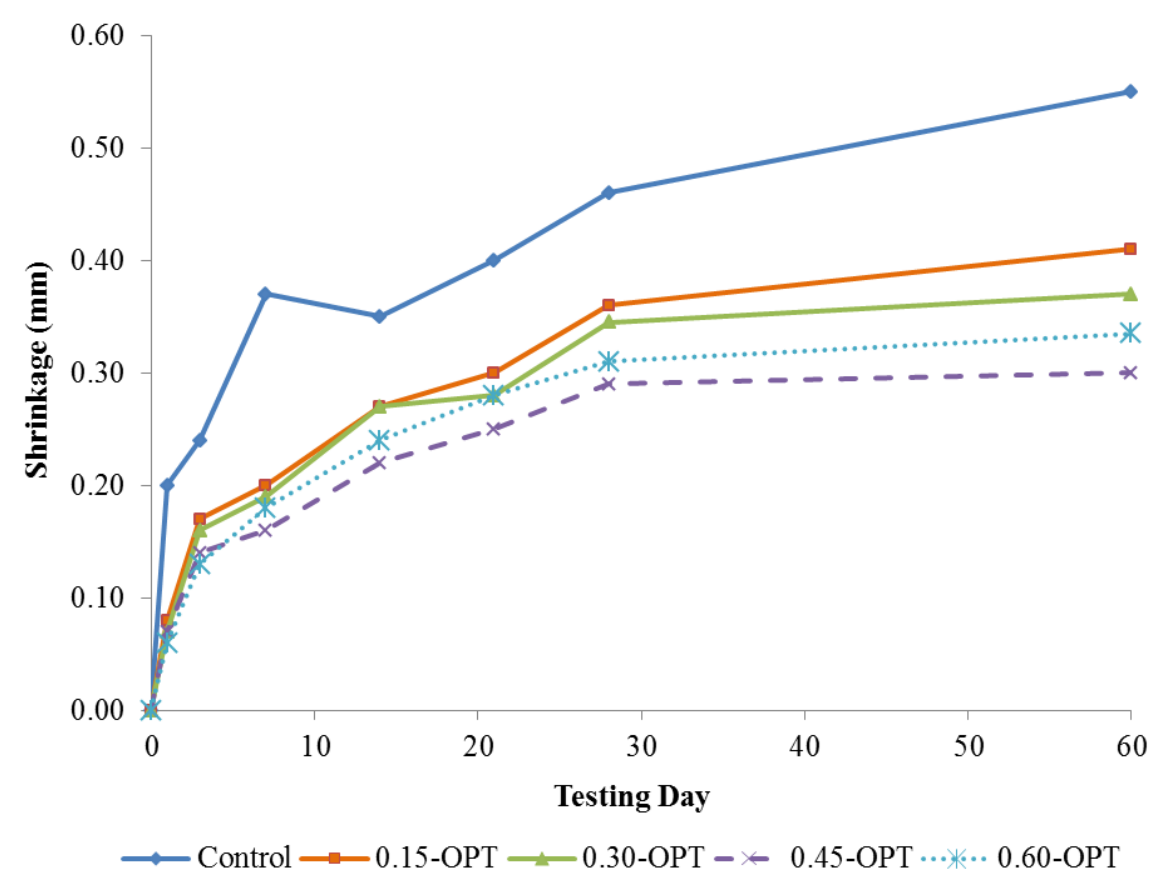

Fig. 4. Drying shrinkage of $600 \mathrm{~kg} / \mathrm{m}^{3}$ density foamcrete of different OPT percentages

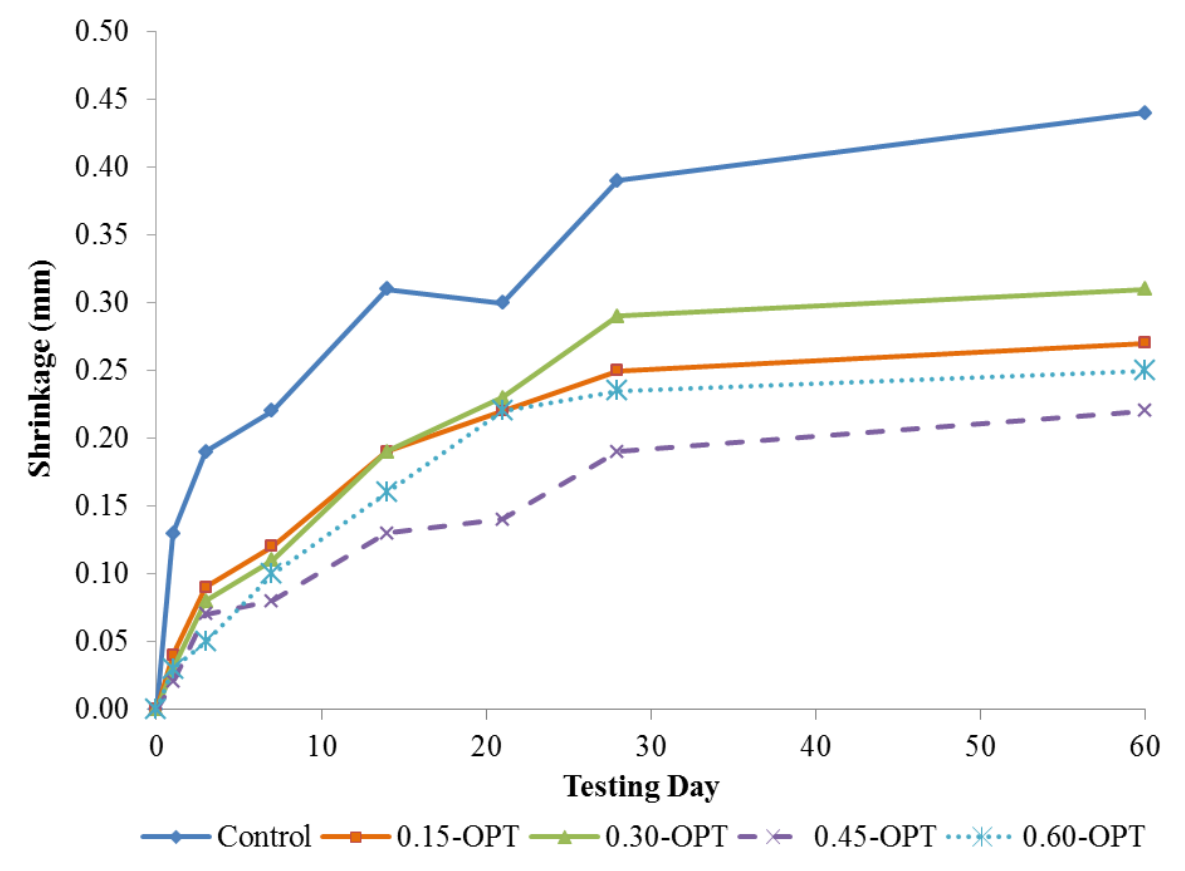

Fig. 5. Drying shrinkage of $1200 \mathrm{~kg} / \mathrm{m}^{3}$ density foamcrete of different OPT percentages 
The increase of OPT percentage in concrete reduces drying shrinkage. Nevertheless, there is no presence of aggregates in the context of foamcrete, which makes it to shrink even more compared to normal strength concrete [14]. Therefore, the inclusion of OPT in foamcrete mix acts as an aggregate due to its capacity of void filling, which consequently reduces the shrinkage effect in the cement matrix. Apart from that, the efficacy of OPT fiber in reducing shrinkage at the same time able to lower the percentage of the cracks of lightweight foamed concrete [15]. Furthermore, OPT fiber has the ability to bridge cracks once the first crack occurs, particularly for the purpose of preventing it from opening. Entrained huge air voids do not alter the physiognomies of fine pore structure of hardened cement matrix substantially [16]. Hence, micro-pores for a specified design mix distress the drying shrinkage that could be equitably connected to the foamcrete paste content. More importantly, the decrease in drying shrinkage value of foamcrete with the addition of OPT contrasted with control mix may likewise be ascribed to the decrease in surface tension of pore water and OPT in the presence of protein based foaming agents which are fundamentally surfactants.

\section{Conclusion}

An experimental study was conducted to evaluate the potential use of oil palm trunk fiber reinforced foamcrete in terms of ultrasonic pulse velocity and drying shrinkage. The study reveals

i. Higher addition of oil palm trunk fiber in the base mix has enhanced the ultrasonic pulse velocity (UPV) in comparison with control specimen. For both densities, $0.45 \%$ oil palm trunk fiber inclusion gave an excellent ultrasonic pulse velocity (UPV) reading. This might be connected to the hydration contrivance of the binary cementitious system in foamcrete for fiber with higher percentages of coconut fiber in the base mix.

ii. OPT enhances the quality and properties of foamcrete. In view of the examination results, the outcome showed that drying shrinkage for all samples is significantly high in early age until 30 days and gradually increases. Meanwhile, the drying shrinkage of foamcrete samples is significantly enhanced through the incorporation of OPT. Overall, it tends to be presumed that the incorporation of OPT in foamcrete adds to better shrinkage resistance and have great embodiment that help to upgrade the strength of foamcrete and enhance ductility.

\section{Acknowledgement}

A sincerely gratitude was dedicated from the authors to Universiti Sains Malaysia as this research was funded by Bridging Grant: Grant No: 304/PPBGN/6316230.

\section{References}

[1] Rahman, Ashiqur, Yern Chee Ching, Kuan Yong Ching, Nur Awanis, Ashok Kumar Chakraborty, Cheng Hock Chuah, and Nai-Shang Liou. "Surface modification of natural fiber using Bi2O3/TiO2 composite for photocatalytic selfcleaning." BioResources 10, no. 4 (2015): 7405-7418.

https://doi.org/10.15376/biores.10.4.7405-7418

[2] Soleimanzadeh, S., and Mydin Ma Othuman. "Influence of high temperatures on flexural strength of foamed concrete containing fly ash and polypropylene fiber." (2013): 117-126. https://doi.org/10.5829/idosi.ije.2013.26.02b.02

[3] Domingo-Cabo, Alberto, Carlos Lázaro, Fernando López-Gayarre, M. A. Serrano-López, P. Serna, and Jesús Orlando Castaño-Tabares. "Creep and shrinkage of recycled aggregate concrete." Construction and building materials 23, no. 7 (2009): 2545-2553. https://doi.org/10.1016/i.conbuildmat.2009.02.018

[4] Mydin, Md Azree Othuman. "Drywall Thermal Properties Exposed to High Temperatures and Fire Condition." Jurnal Teknologi 62, no. 1 (2013).

https://doi.org/10.11113/jt.v62.1369 
[5] Jalal, M. D., Aftab Tanveer, K. Jagdeesh, and Furqan Ahmed. "Foam concrete." International Journal of Civil Engineering Research 8, no. 1 (2017): 1.

[6] Mydin, MA Othuman, M. Musa, and AN Abdul Ghani. "Fiber glass strip laminates strengthened lightweight foamed concrete: Performance index, failure modes and microscopy analysis." In AIP Conference Proceedings, vol. 2016, no. 1, p. 020111. AIP Publishing LLC, 2018. https://doi.org/10.1063/1.5055513

[7] Falliano, D., Domenico, D. De, Ricciardi, G., and Gugliandolo, E. "Mechanical Characterization of Extrudable Foamed Concrete : An Experimental Study." International Journal of Civil and Environmental Engineering 12, no. 3 (2018): 290-294.

[8] Pickering, Kim L., MG Aruan Efendy, and Tan Minh Le. "A review of recent developments in natural fibre composites and their mechanical performance." Composites Part A: Applied Science and Manufacturing 83 (2016): 98-112. https://doi.org/10.1016/i.compositesa.2015.08.038

[9] Mydin, MA Othuman, N. Md Noordin, N. Utaberta, MY Mohd Yunos, and S. Segeranazan. "Physical properties of foamed concrete incorporating coconut fibre." Jurnal Teknologi 78, no. 5 (2016). https://doi.org/10.11113/jt.v78.8250

[10] Olaoye, R. A., J. R. Oluremi, and S. O. Ajamu. "The use of fibre waste as complement in concrete for a sustainable environment." Innovative Systems Design and Engineering 4, no. 9 (2013): 91-97.

[11] Mydin, MA Othuman, N. Md Sani, and M. Taib. "Industrialised building system in Malaysia: A review." In MATEC web of conferences, vol. 10, p. 01002. EDP Sciences, 2014. https://doi.org/10.1051/matecconf/20141001002

[12] Nambiar, EK Kunhanandan, and K. Ramamurthy. "Shrinkage behavior of foam concrete." Journal of materials in civil engineering 21, no. 11 (2009): 631-636. https://doi.org/10.1061/(ASCE)0899-1561(2009)21:11(631)

[13] Bagherzadeh, Roohollah, Hamid Reza Pakravan, Abdol-Hossein Sadeghi, Masoud Latifi, and Ali Akbar Merati. "An investigation on adding polypropylene fibers to reinforce lightweight cement composites (LWC)." Journal of Engineered Fibers and Fabrics 7, no. 4 (2012): 155892501200700410. https://doi.org/10.1177/155892501200700410

[14] Mydin, MA Othuman, N. S. Sahidun, MY Mohd Yusof, and N. Md Noordin. "Compressive, flexural and splitting tensile strengths of lightweight foamed concrete with inclusion of steel fibre." Jurnal Teknologi 75, no. 5 (2015). https://doi.org/10.11113/it.v75.4962

[15] Mydin, MA Othuman, N. A. Rozlan, and S. Ganesan. "Experimental study on the mechanical properties of coconut fibre reinforced lightweight foamed concrete." J. Material and Environmental Sciences 6, no. 2 (2015): 407-411.

[16] Narayanan, N., and K. Ramamurthy. "Structure and properties of aerated concrete: a review." Cement and Concrete composites 22, no. 5 (2000): 321-329. https://doi.org/10.1016/S0958-9465(00)00016-0 